Jasmin Halebić ${ }^{1}$

Alem Merdić ${ }^{2}$

\title{
SHIFT-SHARE EMPLOYMENT ANALYSIS OF CANTONS IN THE FEDERATION OF BOSNIA AND HERZEGOVINA
}

\begin{abstract}
Structure of each economy, especially those in transition, is in constant change. Shift-share analysis is widely used for studying of regional economic change. The model in which the present analysis is conducted has three components: (i) the national growth component (in this paper the entity level of Federation of BH is used as reference level), (ii) the industry mix component, and (iii) the competitive component. Each of them is measured on the basis of employment. The analysis enables assessment of economic performance of a region (here cantons) in comparison to a reference level (here the Federation of Bosnia and Herzegovina).

In this paper authors aimed at capturing economic change at regional level. Authors have compared the economic change in two time periods, 2006-2011 and 2012-2018. Changes in employment are expected in a small transitional and open economy such as Bosnia and Herzegovina. Obtained results indicate that regional economy went through considerable transformation. Some policy recommendations for policy decision-makers in the fields of education and labor market are also given in the paper.
\end{abstract}

Key words: Shift-share analysis, regional economics, employment growth

JEL: $J 21, R 11$

\section{INTRODUCTION}

Each economy is in constant change, those in transition experience economic change of a higher rate. The change can be tracked through variations in variables such as: gross domestic product, productivity, employment, export-import data, etc. Economic transition is especially characterized by changes in employment levels across

1 Associate professor, Faculty of Economics - University of Zenica, 72000, Zenica, Bosnia and Herzegovina (BH), E-mail: jasmin.halebic@ef.unze.ba

2 MA Economics, Teaching Assistant at the Faculty of Economics - University of Zenica, 72000, Zenica, Bosnia and Herzegovina (BH), E-mail: alem.merdic@ef.unze.ba 
economic sectors. Simply, some sectors thrive while other sectors decline in the period of transition from centrally planned to market oriented economies. Following transition process new jobs are created in the expanding sectors requiring new labour skills and in declining sectors the demand for the existing skills falls. Employment levels are not only at the heart of sustainable and inclusive economic growth of a country but also have substantial role in broader social context as well as individual level. Employment is considered to have a pivotal role in people's lives and identities. Some economists argue that unemployment has been one of the major faults of economic systems during history. At broader social level it can be argued that employment analyses can point to social chances and to other potential social challenges such as poverty, crime, migration, etc.

Theoretical background of structural change can be tracked back to 1940-ies at least. Structural change which is expected in transition period can have important effects on employment. If structural change comes together with technological change then an economy can suffer from permanent technological unemployment (Neisser, 1942, p. 71). Therefore, investigating effects on regional level that can create new employment gains utmost importance. Are regional economic structures strong enough or some stimulation from higher levels is needed in order to maintain employment levels in times of structural and technological change? It appears there is agreement among economic profession that several factors including elasticity of product demand and locational advantages and disadvantages of the different regions can play important roles in determining employment effects of structural and technological change (Blien, et al., 2014).

The paper is organised in 5 sections. In the next section the literature review related to shift-share analysis is presented followed by the section in which the standard shift-share model is described. In the fourth section results of the analysis are discussed, while in the last section some concluding remarks and recommendations to policy decision-makers are given.

\section{Literature review}

In a research conducted by Batog \& Batog (2007) total and sectoral employment in $24 \mathrm{EU}$ countries is analysed in two industry classifications, the first one being traditional classification to agriculture, industry and services and the second one being classification into six sectors. Results indicate there is similarity between two classifications. Namely, regional growth (the competitive-effect) accounts for the biggest part of variation in employment growth among countries in each classification of sectors. That means sectoral structure at the beginning of the period (1999) had only small influence on cross-country differences in employment change during the 
period of analysis (2005). With data of almost four decades, 1970-2007, an employment stady was conducted to explore employment growth and its policy implications in West Virginia (USA). It was revealed that primary and secondary sectors are no longer dominant and that tertiary and quandary sectors get prominence in regional economy (Herath, et al., 2011). Shift-share analysis was tested by some authors to examine how this method can be used to distinguish if industrial sectors are suitable for formation of clusters. Based on data from 2003 to 2007 in Czech Republic it was concluded that shift-share analysis "... is only suitable for primary mapping of the dominant sector in the region" (Matatkova \& Stejskal, 2012, p. 945).

Shift-share analysis conducted about cantons in FBH in period of 2006-2011 showed that cantonal competitive advantages contribute to increase in employment in only three out of ten cantons in FBH. In the remaining seven cantons their low competitive advantages were not able to induce economic growth (Halebić \& Merdić, 2013). Similar results were obtained in shift-share analysis of cantons in Croatian economy for period of 1997-2008. In most of Croatian cantons local competitive advantages declined during the period (Čavrak, 2012). Shift-share analysis can also be used for regional comparison between one particular region and a group of other regions (Sims, 2015), or between a region and a national economy as in the case of Malaysia (Hassan, et al., 2011). The location effect in analysis of German regions has been proved significant in regional development (Blien, et al., 2014).

\section{Methodology}

Shift-share analysis compares differences between variable of interest (i.e. employment) on the level of a region in comparison to a reference economy. In this paper the analysis is extended to two periods 2006-2011 and 2012-2018 and economic activities are grouped into sectors. As in our previous paper cantons of the FBH are considered regions and the reference economy is FBH.

From the very beginning during 1940-ies, the shift-share analysis is used as a method for calculation of the components contributing to changes in economic variables, predominantly in changes of employment. For this purpose, the analysis is relevant in assessment and prediction of regional development and growth in employment. Some authors also criticize the analysis on various bases. Standard shift-share analysis relies on three components: (i) the national-growth component, which measures the growth that would have occurred in the event that all industries in the study region had experienced the same rate of growth as the reference area average; ; (ii) the industry-mix component, which measures the growth in the study region attributed to the growth rate of the regional mix of industries; (iii) the competitive or differential-shift component, which attributes regional growth to the dynamism or 
attractiveness of the region and is measured residually (Brox, et al., 2010, p. 27). In the paper this component relates to cantonal level. Shift-share analysis is computed based on the following formulae:

$$
\Delta e_{i}=e_{i}\left[\left(N_{k} / N\right)-1\right]+e_{i}\left[\left(N_{k i} / N_{i}\right)-\left(N_{k} / N\right)\right]+e_{i}\left[\left(e_{k i} / e_{i}\right)-\left(N_{k i} / N_{i}\right)\right]
$$

where: $\Delta \mathrm{ei}$ - employment change in cantons of sector $\mathrm{i} ;{ }^{3}$ ei - employment level in canton of sector $i$ at the beginning of the period; eki - employment level in canton of sector $\mathrm{i}$ at the end of the period; $\mathrm{Nk}$ - total employment in $\mathrm{FBiH}$ at the end of the period; $\mathrm{N}$ - total employment in $\mathrm{FBiH}$ at the beginning of the period; $\mathrm{Nki}$ - total employment in $\mathrm{FBiH}$ at the end of the period in sector $\mathrm{i}$; $\mathrm{Ni}$ - total employment in $\mathrm{FBiH}$ at the end of the period in sector $\mathrm{i}$.

Some authors also use shift-share regression which is not based on deterministic decomposition such as standard shift-share analysis (Blien, et al., 2014). Those who tried both methods, comparing results from standard shift-share analysis and regression based one, observed that "... regression results are generally consistent with each other and with the findings from the traditional shift-share analysis..." (Brox, et al., 2010, p. 38). Based on this observation we decided to run standard shift-share analysis in this paper.

Shift-share analysis in this paper is carried out in two parts, in the first one all activities (from A to T) are grouped into five sectors, starting from primary and ending to quinary sectors as in the table below.

Table 1: Five sectors of the economy in FB\&H

\begin{tabular}{|l|l|l|l|}
\hline & Name of sector & Industry codes & \multicolumn{1}{c|}{ Description } \\
\hline 1 & Primary & A, B & Agriculture, mining \\
\hline 2 & Secondary & C, D, E, F & Industry with construction included \\
\hline 3 & Tertiary & G, H, I, J & Services, including information and communications \\
\hline 4 & Quandary & K, L, M, N & $\begin{array}{l}\text { Financial sector and real estate, with science, technical } \\
\text { and administration activities }\end{array}$ \\
\hline 5 & Quinary & O, P, Q, R, S, T & Activities in domain of public finance \\
\hline
\end{tabular}

Source: (Gelo \& Družić, 2015, pp. 337-338), slightly modified.

In the second part two sectors are defined consisting of traded and non-traded industries. Traded and non-traded sectors are formed based on "Benchmark" approach introduced by IMF (Mano \& Castillo, 2015). If export to gross value added of an industry in FBH in year 2018 is higher than 10\% then the industry is considered traded one. Following that calculation traded sector in FBH consists of industries with codes: A, C and D, while all other industries (B, E to T) are considered non-traded

3 Sectors are primary to quinary, and tradable and non-tradable ones. 
sector. ${ }^{4}$ Although our analysis encompasses 12 years period we have assumed industry tradability fixed through time based on calculation of the export to gross value added ratio only for one year, namely 2018 .

\section{Results}

Results are divided into two groups, the first one related to sectoral shift-share analysis and the second one based on traded and non-traded sectors.

\subsection{Shift-share analysis of five sectors}

Results in the table 2 show that in period 2012-2018 employment level has been increased for 84.273 persons in FBH. This employment increase can be observed in all sectors, from primary to quinary one. In comparison to earlier period 2006-2011 the employment has increased even in primary sector. This employment increase in primary sector in FBH can be related to the growth of the economy of FBH. More precisely, employment in primary sector has increased due to negative industry mix component that shows a fall in competitiveness of that sector in relation to other sectors. Also, low level of competitiveness of industry in primary sector limits rapid growth of employment in that sector in the long term. This is clearly confirmed by the negative industry mix component in period 2006-2018.

In overall increase of employment in period 2012-2018 primary to quinary sectors participate with $3 \%, 33 \%, 39 \%, 14 \%$ and $11 \%$, respectively. When compared with respective results of shift-share analysis in period 2006-2011 it can be stated that share of tertiary and quinary sectors is reduced from $52 \%$ to $39 \%$, and from $29 \%$ to $11 \%$. Employment increase in the tertiary sector in $\mathrm{FBiH}$ is based on positive national- and on industry mix components. Employment increase in the quinary sector is based on positive national component but the reason for reduction of relative contribution of the quinary sector to the employment increase lies in negative industry mix component. Share of the secondary sector in employment increase in period 2012-2018 in comparison with period 2006-2011 has been significantly larger, from $8 \%$ to $33 \%$, that of the primary sector from $-2 \%$ to $3 \%$ and that of quandary sector from $12 \%$ to $14 \%$.

Increase in relative share of the secondary sector in the employment increase in $\mathrm{FBH}$ is based on positive industry mix, component that was negative in earlier period and

4 For different approaches to traded and non-traded sectors see (Gelo \& Družić, 2015). However, we consider tradability of an industry as not country-specific. If some industries are traded in a given country it does not mean those industries are traded in all countries, and vice versa. 
on employment increase of positive national component. When it comes to relative share increase in the primary sector it can be observed that it is based on employment increase of positive national component which is reduced because of negative industry mix component. Relative contribution of the quandary sector to employment increase in period 2012-2018 in comparison to earlier period is supported by positive influence of both national- and industry mix components.

Zenica-Doboj canton contribution to the employment increase in primary sector of $\mathrm{FBiH}$ in period 2012-2018 amounts to $33 \%$ being the largest among other cantons. Central Bosnia Canton and Una-Sana Canton follow with $27 \%$ and 24\%, respectively. Looking into components it is clear that in primary sectors of SBK and USK all three components of shift-share analysis are positive while in Ze-Do Canton primary sector employment increase is supported by positive national component and cantonal competitiveness and lowered by negative industry mix component. The most negative influence on the employment increase in the primary sector of $\mathrm{FBiH}$ is exerted by primary sector of Tuzla Canton (-28\% in relation to the employment increase in that sector), which is caused by negative industry mix component and diminishing in cantonal competitiveness in primary sector of Tuzla Canton. However, this reduction is mitigated by positive influence of national component.

Largest increase in employment in FBH in period 2012-2018 compared to 20062011 is achieved in secondary sector industries. All cantons experienced increase of employment in that sector, and the most significant contribution is given by Central Bosnia Canton with 25\% followed by Tuzla Canton and Zenica-Doboj Canton with 23\% each. In Tuzla Canton and Central Bosnia Canton all three components of shift-share analysis experienced positive values while in Zenica-Doboj Canton negative value of cantonal component was observed which indicates to low level of cantonal competitiveness of that sector in Zenica Doboj Canton.

All cantons achieved employment increase in the tertiary sector, and the largest contribution to it was done by Sarajevo Canton with $29 \%$, followed by Tuzla Canton and Herzegovina-Neretva Canton with $20 \%$ and $17 \%$, respectively. In Tuzla Canton and Herzegovina-Neretva Canton employment increase is established on positive values of all three components in shift-share analysis while in Sarajevo Canton negative value in cantonal component is noticed.

Employment increase in quandary sector in period 2012-2018 related to the earlier period amounts to $74 \%$ and is dominantly held up by employment increase in this sector in KS with $65 \%$ participation in the increase. Additionally, largest contribution to employment increase in this sector is noticed in ZDK and TK with $12 \%$ and $11 \%$, respectively. In KS and ZDK all three components of shift-share analysis are positive while in TK cantonal component has negative value. This increase in employment 
of quandary sector in $\mathrm{FBiH}$ in period 2012-2018 is lowered by employment fall in quandary sector in HNK (by $-7 \%$ in comparison to overall increase in employment of quandary sector) which is, in return, induced by low cantonal competitiveness and industry mix component. In period 2006-2011 in HNK cantonal component was negative together with positive increase in employment in quandary sector. In period 2012-2018 the fall in cantonal competitive advantages in quandary sector neutralized all positive effects of national- and industry mix components in employment, meaning that there has been significant reduction of cantonal competitiveness in this sector of HNK in the long term.

Quinary sector in FBH in period 2012-2018 experienced employment increase of 9.210 persons with the highest contribution in this increase accomplished by Sarajevo Canton, Zenica-Doboj Canton, Tuzla Canton and Herzegovina-Neretva Canton with $27 \%, 19 \%, 19 \%$ and 18 , respectively. Interestingly, industry mix component in all cantons was negative which indicates to the low level of competitiveness of this sector in relation to the average competitiveness of other sectors in FBiH. West-Herzegovina Canton is the canton with decrease in employment level in quinary sector ( $-2 \%$ in comparison to the quinary sector employment increase in $\mathrm{FBiH}$ in period 2012-2018). With regard to the facts that West Herzegovina Canton achieved the highest increase of employment in quinary sector in period 2006-2011, and that in period 2012-2018 all sectors in West Herzegovina Canton, except the quinary one, witnessed increase in employment it is fair to say that competitiveness of the quinary sector, related to all others, has been reduced. 
Table 2: Shift-share analysis of five sectors in FB\&H and cantons

\begin{tabular}{|c|c|c|c|c|c|c|c|c|c|}
\hline \multirow[b]{2}{*}{ Area } & \multirow[b]{2}{*}{ Sectors } & \multicolumn{4}{|c|}{ 2006-2011, shift-share } & \multicolumn{4}{|c|}{ 2012-2018, shift-share } \\
\hline & & $\begin{array}{c}\text { total } \\
\text { change }\end{array}$ & $\begin{array}{c}\text { national } \\
\text { growth } \\
\text { component }\end{array}$ & $\begin{array}{c}\text { industry mix } \\
\text { component }\end{array}$ & $\begin{array}{l}\text { competitive } \\
\text { component }\end{array}$ & $\begin{array}{c}\text { total } \\
\text { change }\end{array}$ & $\begin{array}{c}\text { nacional } \\
\text { growth } \\
\text { component }\end{array}$ & $\begin{array}{c}\text { industry } \\
\text { mix } \\
\text { component }\end{array}$ & $\begin{array}{c}\text { competitive } \\
\text { component }\end{array}$ \\
\hline \multirow{5}{*}{ FBiH } & primary & -1.155 & 3.380 & -4.535 & 0 & 2.261 & 4.254 & -1.994 & 0 \\
\hline & secondary & 4.522 & 16.916 & -12.393 & 0 & 27.930 & 23.428 & 4.502 & 0 \\
\hline & tertiary & 28.291 & 14.553 & 13.739 & 0 & 33.226 & 25.243 & 7.982 & 0 \\
\hline & quaternary & 6.684 & 3.322 & 3.362 & 0 & 11.646 & 6.042 & 5.605 & 0 \\
\hline & quinary & 15.904 & 16.076 & -172 & 0 & 9.210 & 25.305 & -16.095 & 0 \\
\hline \multirow{5}{*}{ USK } & primary & 83 & 167 & -211 & 127 & 546 & 231 & 250 & 65 \\
\hline & secondary & -1.630 & 1.426 & -1.058 & -1.998 & 2.184 & 1.532 & 201 & 451 \\
\hline & tertiary & 2.423 & 1.113 & 1.164 & 146 & 2.362 & 1.924 & 843 & -405 \\
\hline & quaternary & -134 & 270 & 9 & -413 & 619 & 343 & 297 & -20 \\
\hline & quinary & 683 & 1.492 & -12 & -797 & 292 & 2.190 & -1.512 & -386 \\
\hline \multirow{5}{*}{ PK } & primary & -59 & 33 & -42 & -50 & 13 & 33 & 36 & -56 \\
\hline & secondary & -167 & 240 & -177 & -230 & 383 & 307 & 80 & -4 \\
\hline & tertiary & -460 & 338 & 392 & -1.190 & 214 & 379 & 137 & -302 \\
\hline & quaternary & -94 & 36 & 72 & -202 & 72 & 35 & 27 & 10 \\
\hline & quinary & 81 & 258 & -9 & -168 & 77 & 373 & -277 & -19 \\
\hline \multirow{5}{*}{ TK } & primary & -322 & 1.362 & -1.871 & 187 & -624 & 1.719 & -1.908 & -435 \\
\hline & secondary & 3.177 & 3.325 & -2.419 & 2.271 & 6.522 & 5.006 & 1.193 & 323 \\
\hline & tertiary & 5.950 & 2.276 & 1.927 & 1.747 & 6.787 & 4.172 & 997 & 1.618 \\
\hline & quaternary & 1.201 & 393 & 216 & 592 & 1.270 & 791 & 685 & -206 \\
\hline & quinary & 1.647 & 2.863 & -56 & -1.160 & 1.739 & 4.166 & -2.652 & 224 \\
\hline \multirow{5}{*}{ ZDK } & primary & -478 & 960 & -1.303 & -135 & 737 & 1.200 & -1.019 & 556 \\
\hline & secondary & 979 & 3.995 & -2.907 & -109 & 6.483 & 5.324 & 1.647 & -488 \\
\hline & tertiary & 2.533 & 2.005 & 1.692 & -1.164 & 3.586 & 3.175 & 966 & -555 \\
\hline & quaternary & 203 & 380 & 365 & -542 & 1.442 & 547 & 424 & 471 \\
\hline & quinary & 1.031 & 2.214 & -18 & -1.165 & 1.791 & 3.229 & -2.153 & 715 \\
\hline \multirow{5}{*}{ BPK } & primary & 23 & 13 & -16 & 26 & 55 & 22 & 30 & 3 \\
\hline & secondary & 886 & 233 & -173 & 826 & 721 & 590 & 286 & -155 \\
\hline & tertiary & 225 & 114 & 117 & -6 & 265 & 201 & 67 & -3 \\
\hline & quaternary & 21 & 19 & 35 & -33 & 84 & 29 & 23 & 33 \\
\hline & quinary & 194 & 223 & -12 & -17 & 130 & 344 & -282 & 68 \\
\hline \multirow{5}{*}{ SBK } & primary & -388 & 378 & -494 & -272 & 608 & 438 & 57 & 113 \\
\hline & secondary & -107 & 1.882 & -1.392 & -597 & 7.024 & 2.533 & 892 & 3.599 \\
\hline & tertiary & 907 & 1.517 & 1.677 & -2.287 & 2.614 & 2.216 & 875 & -477 \\
\hline & quaternary & 11 & 127 & 178 & -294 & 901 & 172 & 134 & 596 \\
\hline & quinary & 1.766 & 1.373 & -69 & 462 & 1.091 & 2.240 & -1.382 & 233 \\
\hline \multirow{5}{*}{ HNK } & primary & -74 & 124 & -158 & -40 & 238 & 146 & 123 & -31 \\
\hline & secondary & -1.106 & 1.715 & -1.242 & -1.579 & 1.940 & 2.214 & -67 & -207 \\
\hline & tertiary & 856 & 1.767 & 1.717 & -2.628 & 5.695 & 2.647 & 900 & 2.148 \\
\hline & quaternary & 805 & 466 & 694 & -355 & -827 & 881 & 1.252 & -2.961 \\
\hline & quinary & 1.887 & 1.919 & 118 & -150 & 1.642 & 3.031 & -1.192 & -197 \\
\hline \multirow{5}{*}{ ZHK } & primary & -159 & 64 & -83 & -140 & 330 & 55 & -4 & 279 \\
\hline & secondary & 366 & 513 & -382 & 235 & 848 & 831 & 187 & -170 \\
\hline & tertiary & 373 & 904 & 1.156 & -1.687 & 1.437 & 1.284 & 408 & -255 \\
\hline & quaternary & -182 & 142 & 42 & -366 & 417 & 168 & 160 & 89 \\
\hline & quinary & 1.285 & 460 & 34 & 791 & -172 & 894 & -266 & -800 \\
\hline \multirow{5}{*}{ KS } & primary & 190 & 143 & -182 & 229 & 10 & 225 & 263 & -478 \\
\hline & secondary & 2.857 & 3.152 & -2.326 & 2.031 & 1.751 & 4.666 & 79 & -2.994 \\
\hline & tertiary & 15.602 & 4.128 & 3.494 & 7.980 & 9.791 & 8.733 & 2.595 & -1.537 \\
\hline & quaternary & 5.008 & 1.431 & 1.700 & 1.877 & 7.573 & 3.021 & 2.561 & 1.991 \\
\hline & quinary & 7.097 & 4.805 & -139 & 2.431 & 2.458 & 8.139 & -5.837 & 156 \\
\hline \multirow{5}{*}{ K10 } & primary & 29 & 137 & -175 & 67 & 348 & 186 & 178 & -16 \\
\hline & secondary & -733 & 436 & -319 & -850 & 74 & 425 & 4 & -355 \\
\hline & tertiary & -118 & 390 & 403 & -911 & 475 & 513 & 195 & -233 \\
\hline & quaternary & -155 & 58 & 50 & -263 & 95 & 56 & 41 & -2 \\
\hline & quinary & 233 & 470 & -9 & -228 & 162 & 698 & -541 & 5 \\
\hline
\end{tabular}

Source: authors. Legend: FB\&H-Federation of Bosnia and Herzegovina; USK - Una-Sana canton; PK - Posavina canton; TK - Tuzla canton; ZDK-Zenica-Doboj canton; BPK - Bosnian-Podrinje canton; SBK - Central Bosnia canton; HNK-Herzegovina-Neretva-

canton; ZHK-West-Herzegovina canton; KS - Sarajevo canton; K10 - Canton 10. 


\subsection{Shift-share analysis of traded and non-traded sectors in FB\&H}

Since $\mathrm{BiH}$ is a small and open economy that participates in the process of globalization through various economic integrations, it is quite reasonable to explore the effects of these integration processes on employment and its structure. Analysis of change in structure of employment in FBH and its ten cantons is presented in Table 3. The analysis is decomposed to two sectors: traded and non-traded with three shift-share components and two periods 2006-2011 and 2012-2018.

In the first period an increase in employment in FBH by 54.246 persons can be observed with only 3.275 new jobs, or $6 \%$, in tradeable goods sector and the remaining 50.971 new jobs, or $94 \%$ in non-traded sector. In second period, employment in FBH increased for 84.273 persons out of which 28.215 persons, or $33 \%$, have been employed in traded sector and the remaining 56.058 jobs, or $67 \%$, in non-traded sector. These figures show a change in economy of $\mathrm{FBiH}$ and cantons, with 27 percentage points growth of employment in traded sector between these two periods. This change in employment structure is joined with higher economic integration of $\mathrm{BiH}$ and the world that was induced by the Stability and association agreement (SAA) between $\mathrm{BiH}$ and the EU, among other things. SAA envisions formation of a free-trade zone with the EU member country along with trade liberalization with the EFTA member countries. Furthermore, size of trade in CEFTA 2006 has been continually increasing.

Employment increase in tradable goods sector is linked to positive national- and industry mix components in $\mathrm{FBiH}$, and employment increase in non-traded sector can be associated to positive national component. Negative values of industry mix component in non-traded sector imply that an increase in competitiveness in traded sector is followed by decrease in competitiveness in non-traded sector.

All cantons experienced higher employment growth in non-traded sectors in 20122018 in comparison with the earlier period. In traded sectors only KS and PBK have less employment growth compared to period 2006-2011. Contribution to the employment increase in 2012-2018 in traded sector is at the highest level in ZDK and SBK with $25 \%$ each, and in TK with 19\%. Employment achieved in SBK in traded sector is induced by all three positive components of shift-share analysis, while ZDK and TK have negative value of cantonal component that causes reduction in the employment growth.

Considering non-tradable goods sector, the largest contribution to increase in employment in $\mathrm{FBiH}$ in period 2012-2018 is given by KS, TK and ZDK, with 36\%, $18 \%$ and $13 \%$, respectively. This employment increase in KS is associated with positive value of national component and lessened by negative values in industry mix and cantonal components in non-traded sector. 
The employment increase in TK in non-traded sector is connected to positive national- and cantonal components and diminished by negative industry mix component for $-35 \%$. The employment increase in ZDK in non-traded sector is linked to positive values in national- and cantonal components and reduced by industry mix component for $-36 \%$. As expected, KS manifests highest contribution to increase in employment in non-traded sector in FBH since it is largest administrative and financial centre in $\mathrm{BH}$.

Table 3: Shift-share analysis of traded and non-traded sectors of the economy of canton

\begin{tabular}{|c|c|c|c|c|c|c|c|c|c|}
\hline \multirow[b]{2}{*}{ Area } & \multirow[b]{2}{*}{ Sectors } & \multicolumn{4}{|c|}{ 2006-2011, shift-share } & \multicolumn{4}{|c|}{ 2012-2018, shift-share } \\
\hline & & $\begin{array}{c}\text { total } \\
\text { change }\end{array}$ & \begin{tabular}{|c|} 
national \\
growth \\
component
\end{tabular} & $\begin{array}{l}\text { industry } \\
\text { mix } \\
\text { component }\end{array}$ & $\begin{array}{l}\text { competitive } \\
\text { component }\end{array}$ & $\begin{array}{c}\text { total } \\
\text { change }\end{array}$ & $\begin{array}{c}\text { nacional } \\
\text { growth } \\
\text { component }\end{array}$ & $\begin{array}{l}\text { industry } \\
\text { mix } \\
\text { component }\end{array}$ & $\begin{array}{l}\text { competitive } \\
\text { component }\end{array}$ \\
\hline \multirow{2}{*}{$\mathrm{FBiH}$} & traded & 3.275 & 13.712 & -10.436 & 0 & 28.215 & 18.946 & 9.269 & 0 \\
\hline & non-traded & 50.971 & 40.534 & 10.437 & 0 & 56.058 & 65.327 & -9.269 & 0 \\
\hline \multirow{2}{*}{ USK } & traded & -1.541 & 1.167 & -926 & -1.782 & 2.751 & 1.206 & 739 & 806 \\
\hline & non-traded & 2.966 & 3.300 & 819 & -1.153 & 3.253 & 5.013 & -660 & -1.100 \\
\hline \multirow{2}{*}{ PK } & traded & 19 & 185 & -146 & -20 & 455 & 273 & 151 & 31 \\
\hline & non-traded & -718 & 720 & 382 & -1.820 & 303 & 854 & -149 & -402 \\
\hline \multirow{2}{*}{ TK } & traded & 1.855 & 2.838 & -2.098 & 1.115 & 5.348 & 4.112 & 1.970 & -734 \\
\hline & non-traded & 9.798 & 7.379 & -104 & 2.523 & 10.346 & 11.741 & -3.654 & 2.259 \\
\hline \multirow{2}{*}{ ZDK } & traded & 1.545 & 3.384 & -2.552 & 713 & 6.929 & 4.649 & 2.415 & -135 \\
\hline & non-traded & 2.723 & 6.169 & 382 & -3.828 & 7.110 & 8.825 & -2.549 & 834 \\
\hline \multirow{2}{*}{ BPK } & traded & 965 & 199 & -151 & 917 & 795 & 561 & 341 & -106 \\
\hline & non-traded & 384 & 401 & 104 & -121 & 460 & 627 & -219 & 52 \\
\hline \multirow{2}{*}{ SBK } & traded & -428 & 1.823 & -1.450 & -801 & 7.060 & 2.395 & 1.410 & 3.255 \\
\hline & non-traded & 2.617 & 3.455 & 1.350 & -2.188 & 5.178 & 5.205 & -835 & 809 \\
\hline \multirow{2}{*}{$\mathrm{HNK}$} & traded & -996 & 1.318 & -975 & -1.339 & 1.876 & 1.676 & 403 & -203 \\
\hline & non-traded & 3.364 & 4.673 & 2.104 & -3.413 & 6.812 & 7.243 & 614 & -1.045 \\
\hline \multirow{2}{*}{ ZHK } & traded & 230 & 394 & -312 & 148 & 949 & 626 & 325 & -2 \\
\hline & non-traded & 1.453 & 1.688 & 1.080 & -1.315 & 1.911 & 2.605 & 161 & -854 \\
\hline \multirow{2}{*}{ KS } & traded & 2.126 & 1.984 & -1.464 & 1.606 & 1.517 & 3.009 & 1.225 & -2.717 \\
\hline & non-traded & 28.628 & 11.676 & 4.010 & 12.942 & 20.066 & 21.775 & -1.564 & -145 \\
\hline \multirow{2}{*}{ K10 } & traded & -500 & 418 & -361 & -557 & 535 & 438 & 291 & -194 \\
\hline & non-traded & -244 & 1.072 & 311 & -1.627 & 619 & 1.439 & -413 & -407 \\
\hline
\end{tabular}

Source: authors.

\subsection{Concluding remarks and recommendations}

Results of shift-share analysis make a solid basis to decision-makers for policy creation processes aimed at enhancing the economic growth. One of policies that is closely related to the results is education policy. Analysis in this paper has shown that employment structure changes in the long term, both in $\mathrm{FBiH}$ and cantons. Those sectors with high cantonal competitive components and potential for creation of new jobs should be provided by labour market with educated persons whose qualifications closely match and comply to sectoral labour force requirements. In this way competitive advantages of those sectors will be more strengthened which is a prerequisite for sustainable economic growth. 


\section{REFERENCES}

1. Batog, B. \& Batog, J., 2007. Shift-share Analysis of Employment Growth within the EU Countries in 1999-2005. In: D. Kopycinska, ed. EU Countries in 1999-2005. Szczecin/Poland: University of Szczecin, pp. 45-55.

2. Blien, U., Eigenhueller, L., Promberger, M. \& Schanne, N., 2014. The Shift-Share Regression: An Application to Regional Employment Development. In: K. kourtit, P. Nijkamp \& R. Stimson, eds. Applied REgional Growth and Innovation Models. Palermo, Italy: Springer, pp. 109-139.

3. Brox, J., Carvalho, E. \& Mackay, J., 2010. Regional Employment Changes in a Booming Resource Economy: A Modified Shift-Share Analogue Regression of Changes in Employment Patterns within the Economic Regions of Alberta. Canadian Journal of Regional Science, 33(2), pp. 25-44.

4. Čavrak, V., 2012. Shift-share analysis of the Croatian counties. Proceedings of the Economics Faculty in Zagreb, 10(2), pp. 79-96.

5. Gelo, T. \& Družić, M., 2015. Total factor productivity of sectors in the economy of Croatia. Ekonomska misao i praksa, XXIV(2), pp. 327-344.

6. Halebić, J. \& Merdić, A., 2013. A contribution to the study of developmental characteristics of cantons in Federation of Bosnia and Herzegovina. BH Ekonomski Forum, Issue 5, pp. 55-73.

7. Hassan, M., Rashid, Z. \& Hamid, K., 2011. East Coast Economic Region From The Perspective Of Shift-Share Analysis. International Journal of Business and Society, 12(1), pp. 79-88.

8. Herath, J., Gebremedhin, T. \& Maumbe, B., 2011. A Dynamic Shift Share Analysis of Economic Growth in West Virginia. Journal of Rural and Community Development, 6(2), pp. 155-169.

9. Mano, R. \& Castillo, M., 2015. The Level of Productivity in Traded and Non-Traded Sectors for a Large Panel of Countries. IMF Working Paper, February, pp. 1-49.

10. Matatkova, K. \& Stejskal, J., 2012. Assessment of Shift-share Analysis Suitable for Identification of Industrial Cluster Establishing in Regions. Ekonomicky časopis, 60(9), pp. 935-948.

11. Neisser, H., 1942. 'Permanent' Technological Unemployment: 'Demand for Commodities Is Not Demand for Labor. The American Economic Review, 32(1), pp. 50-71.

12. Sims, N., 2015. Shift-Share Analysis $>$ A Further Review of Employment Growth in the Sangamon County Economic Area, Illinois: The Springfield-Sangamon County Regional Planning Commission. 


\section{SHIFT-SHARE ANALIZA ZAPOSLENOSTI KANTONA U FEDERACIJI BOSNE I HERCEGOVINE}

\section{SAŽETAK}

Struktura svake privrede, posebno onih u tranziciji, se stalno mijenja. Shift-share analiza ima široku primjenu u proučavanju regionalnih ekonomskih promjena. Primjenjeni model za analizu promjene strukture zaposlenosti, u ovom radu, sastoji se od tri komponente: (i) komponenta nacionalnog rasta (za potrebe ovog rada, entitet Federacija Bosne i Hercegovine se koristi kao refereni nivo), (ii) industrijska miks komponenta i (iii) komponenta kantonalne konkurentnosti. Svaka od navedenih komponenti se mjeri putem pokazatelja broja zaposlenih. Provedena analiza omogućava procjenu ekonomskih performansi posmatranih regiona (u ovom slučaju kantona), $u$ odnosu na referentni nivo (Federacija Bosne i Hercegovine).

Cilj ovog rada je analiza ekonomskih promjena, mjerenih putem pokazatelja apsolutne zaposlenosti, na regionalnom nivou. Autori prave komparaciju ekonomskih promjena u dva posmatrana perioda, 2006-2011 i 2012-2018. Promjene u zaposlenosti, u maloj i otvorenoj ekonomiji, kao što je Bosna i Hercegovina su očekivane. Dobijeni rezultati ukazuju na to da regionalne privrede prolaze kroz značajne transformacije kroz vrijeme. U radu se, također, date i određene preporuke za kreatore politika koje se odnose na oblast obrazovanja i tržišta rada.

Ključne riječi: Shift-share analiza, regionalna ekonomija, rast zaposlenosti

JEL: $J 21, R 11$ 